\title{
Development and Performance Evaluation of Cup-Chain type Metering Mechanism for Gladiolus corms in the Soil Bin
}

\author{
T. M. Ananda Kumar* and T. P. Singh \\ Department of FMPE, College of Technology, GBPUA\&T, Pantnagar, Uttarakhand, India \\ *Corresponding author
}

\section{A B S T R A C T}

Gladiolus is a very popular flowering plant grown for its elegant cut spike. Presently, the Gladiolus corms are planted manually which is time and labour intensive process. It also

\section{Keywords}

Planter, Gladiolus, Metering device and cup-chain

Article Info

Accepted: 22 July 2019 Available Online: 10 August 2019 involves considerable amount of drudgery. Till date very little work on mechanized planting of corms has been reported. In order to carry out the panting operation in specific time and to mechanize this operation for Gladiolus crop, a cup-chain type metering mechanism was developed and its performance was evaluated in linear soil bin. The experiment was conducted for three levels of nominal spacings $(15,20$ and $25 \mathrm{~cm})$ and four levels of forward speeds $(1.5,2.0,2.5$ and $3.0 \mathrm{~km} / \mathrm{h})$. The performance parameters namely, mean spacing, multiple index, missing index, quality feed index, coefficient of uniformity, precision, coefficient of precision (CP3), visible damage and number of corms per meter length were determined. The data was statistically analyzed using two factorial completely randomized design (CRD).The results indicated that the metering mechanism was able to drop the corms at desired nominal spacing at forward speed of $1.5 \mathrm{~km} / \mathrm{h}$ with $100 \%$ quality feed index. The precision was found less than $10 \%$ for all the three nominal spacings and four forward speeds. The overall performance of metering mechanism was found better for $25 \mathrm{~cm}$ nominal spacing at forward speeds of 1.5 and $2.0 \mathrm{~km} / \mathrm{h}$.

\section{Introduction}

Floriculture is a fast emerging venture in the world, especially as a potential money-spinner for many third world countries. Many flowers and ornamental plants are being grown for domestic as well as for export market that provide more return per unit area than any other food grain crops. The government sets its focus on floriculture sector with the hope of robust growth in the future to help boost and stabilize the country's economy as well as increase the opportunities for the employment.
Nowadays, growing of cut flower crops suitable for flower arrangements/decorations, bouquets preparation and floral baskets has increased substantially and so its share in the total trade. Gladiolus is high value ornamental flowering crop, which is mainly grown for its elegant cut spike. It is the second most popular commercial cut flower next to rose but ranks first, both in area and production as well as return per unit area, among the bulbous crop grown in the country. The total area under Gladiolus cultivation in the country during 2016-17 was 11660 ha with a production of 
50700 MT as loose flowers and 92.89 lakh (in numbers) as cut flowers (Anonymous, 201617).

Manual planting of Gladiolus corms is a time and labour-intensive operation. Besides of large number of labour requirement, it also involves considerable drudgery and human discomfort. Shortage of agricultural labor and increased wages delays the planting operation and also makes it uneconomical. Therefore, in order to reduce farmer's dependency on manual labor for planting of this crop, there is need to develop a suitable planter with efficient metering mechanism. Till date very little work has been reported on this aspect. Rad (2006) developed and evaluated a two row planter for saffron corms that was able to plant the corms at a row spacing of $22 \mathrm{~cm}$ with planting depth of $15 \mathrm{~cm}$ without damaging the corms. The cup chain type metering mechanism was used in the planter. Singh and Singh (2017) developed single row planter for gladiolus corms. The wooden cup on chain type mechanism was used in the planter. The planter was able to perform satisfactorily at forward speed of 1.5 to $2.0 \mathrm{~km} / \mathrm{h}$. planter for gladiolus corms and the performance was evaluated in field condition. The planter In view of the above, the present study was under taken to develop

\section{Materials and Methods}

A cup chain type metering mechanism was developed and evaluated in linear soil bin for Gladiolus corms. The metering mechanism consisted of cups, chain, hopper, shafts with ball bearings, main frame and delivery pipe. The schematic diagram of cup chain type metering mechanism is shown in Fig. 1.

Thirteen numbers of circular cups of size 45 $\mathrm{mm}$ in diameter (equivalent to mean diameter of Gladiolus corms) with $25 \mathrm{~mm}$ depth was fitted on $130 \mathrm{~cm}$ long roller type chain. The spacing between sups was kept $100 \mathrm{~mm}$. Chain was fitted on two sprockets i.e. upper and lower sprockets with 18 and 11 number of teeth. Both the sprockets have been fitted on a MS shaft of $25 \mathrm{~mm}$ in diameter. This cup chain system was finally mounted on a rectangular frame. The frame was made to support the hopper, metering unit and delivery pipe. The overall dimensions of frame was $1100 \times 250 \times 250 \mathrm{~mm}$ (Length $\times$ width $\times$ breadth) in size. The frame was fabricated from MS angle of size $35 \times 3 \mathrm{~mm}$. The hopper was fabricated in trapezoidal shape from MS sheet of $2 \mathrm{~mm}$ thickness. The wall inclination of the hopper was kept $45^{\circ}$ from the vertical for easy flow of the corms towards the bottom of the hopper. The power to metering mechanism was provided through ground wheel of size $320 \mathrm{~mm}$ diameter with different gear ratios to maintain the nominal spacings.

\section{Working principle of metering device}

The metering device received power from ground wheel with a suitable chain and sprocket system. The cups fixed on chain pick-ups the corms from hopper as the chain moves from bottom to top of metering device and drop the corms into delivery pipe. The corms will fall into furrow safely through delivery pipe.

\section{Performance evaluation}

The performance evaluation of metering mechanism was conducted in the linear soil bin available in the department of Farm Machinery and Power Engineering, College of Technology GBPUA\&T Pantnagar (Fig 2). The experiment was conducted at four levels of forward speeds $(1.5,2.0,2.5$ and $3.0 \mathrm{~km} / \mathrm{h})$ and three levels of nominal spacings $(15,20$ and $25 \mathrm{~cm}$ ). The performance indexes viz.mean spacing, multiple index, missing index, quality of feed index, coefficient of uniformity, precision, coefficient of precision, visible 
corm damage and number of corms dropped per meter length were determined. The data were analyzed statistically using two factorial completely randomized design (CRD).

\section{Soil bin}

A rectangular soil bin of length, width and height of $25,1.2$ and $1 \mathrm{~m}$ was used to test the metering mechanism under controlled condition. The soil bin is made of reinforced cement concrete and on both the side $0.228 \mathrm{x}$ $0.228 \mathrm{~m}$ bricks posts are provided over which two side rails of $1 \times 0.5 \mathrm{~m}$ of channel sections are mounted along the length of bin (Fig. 2). The side rails are used to facilitate the linear movement of a trolley which has provisions for changing the forward speeds. The trolley can be moved both forward and backward with the help of an electric motor (3 phase, 10 $\mathrm{hp}$ and $1440 \mathrm{rpm}$ ). The soil bin is filled with locally available silty clay loam soil, for conducting the experiment up to a depth of 0.6 $\mathrm{m}$. The moving trolley of soil bin has facility for soil preparation and leveling of the same.

\section{Mean spacing}

The corm to corm spacing was measured with the help of measuring tape for each test run (Singh and Singh, 2017). Three replications were taken for combination of experiment and thereafter the mean spacing was calculated by the following relationship.

$$
\bar{X}=\sum_{i=1}^{N} \frac{X_{1}}{N}
$$

Where, $\overline{\mathrm{X}}=$ Mean spacing, $\mathrm{cm}, \mathrm{X}_{\mathrm{i}}=$ distance between the $i^{\text {th }}$ corm and next corm, $\mathrm{cm}$ $\mathrm{N}=$ total number of spacings measured

\section{Miss index (MISS)}

The corm to corm spacing observed either equal or greater than 1.5 times the nominal spacing of the corm is considered as miss index (MISS). The miss index was calculated using following relationship as suggested by Yazgi and Degirmencioglu, 2014.

Missing Index, $\%=\frac{\mathrm{n}_{1}}{\mathrm{~N}} \times 100$

Where, $\mathrm{n}_{1}=$ Number of spacings $\geq 1.5$ times the nominal spacing, $\mathrm{N}=$ Total number of measured spacings

\section{Multiple index (MULTI)}

The corm to corm spacing observed equal or less than 0.5 times the nominal spacing of the cormis considered as multiple indexes (MULTI). The multiple index was determined using following relationship as suggested by Yazgi and Degirmencioglu, 2014.

MultipleIndex, $\%=\frac{\mathrm{n}_{2}}{\mathrm{~N}} \times 100$

Where, $\mathrm{n}_{2}=$ number of spacing $\leq 0.5$ times the nominal spacing, $\mathrm{N}=$ Total number of measured spacing.

\section{Quality feed index (QFI)}

The quality feed index is the percentage of spacings that are greater than half but not greater than 1.5 times the nominal spacing spacing.

Jinqing et al., 2016 suggested the following equation to determine the quality feed index.

Quality of feed Index, $\%=\frac{\mathrm{n}_{3}}{\mathrm{~N}} \times 100$

Where, $\mathrm{n}_{3}=$ Number of corms spacing that are $>0.5$ times and $<1.5$ times the nominal spacing, $\mathrm{N}=$ Total number of measured spacing. 


\section{Coefficient of Uniformity (CU)}

In order to determine the evenness of corm placement in row by the metering device, the average value of observed corm spacing was determined and then coefficient of uniformity was calculated using the following equation.

Coefficient of uniformity $\left(\mathrm{C}_{\mathrm{u}}\right)=1-\left[\frac{(\mathrm{X}-\overline{\mathrm{X}}) \mid}{\mathrm{N} \overline{\mathrm{X}}}\right] \times 100$

$\mathrm{C}_{\mathrm{u}}=$ Coefficient of uniformity, $\%, \mathrm{X}=$ sum of absolute value, $\mathrm{cm}, \overline{\mathrm{X}}=$ Nominal spacing, $\mathrm{cm}, \mathrm{N}=$ Number of observation

\section{Coefficient of precision (CP3)}

It is defined as percentage of corms spacing that fall within $\pm 1.5 \mathrm{~cm}$ of nominal spacing. It is also known as $3 \mathrm{~cm}$ mode range. Brinkmann et al., (1980) proposed the use of a new parameter called coefficient of precision (CP3) for comparison of seed spacing.

This parameter was proposed to be a better representation of the ability of a precision planter to place seeds closer to the actual required spacing than using the combination of average spacing and standard deviation. The mean values of the coefficient of precision were calculated using the following equation.

$\mathrm{CP} 3=\frac{\mathrm{N}_{\mathrm{b}}}{\mathrm{T}_{b}} \times 100$

Where, CP3 $=$ Coefficient of precision, $\%, \mathrm{~N}_{\mathrm{b}}$ $=$ Number of corms dropped within $\pm 1.5 \mathrm{~cm}$ range from nominal spacing, $\mathrm{T}_{\mathrm{b}}=$ Total number of corms dropped

\section{Precision}

Precision (PREC) is a measure of the variability in spacing after accounting for variability due to both multiples and skips (Bracy and Parish, 1999).

$\mathrm{PREC}=\mathrm{S}_{2} / \mathrm{X}_{\mathrm{ref}} \ldots$ (7)

Where,

$\mathrm{S}_{2}=$ Standard deviation of the $\mathrm{n}_{3}$ observations i.e. spacing between 0.5 to 1.5 times the nominal spacing, $X_{\text {ref }}=$ nominal spacing, $\mathrm{cm}$

\section{Visible damage}

The percentage of visible damage caused by metering device was calculated by observing the physical damage to the corms after passing through the metering mechanism. The corms dropped in the furrow were collected and observed for any physical damage and the data related to the same was recorded. The percentage of visible corm damage was calculated using the following relationship.

Visible damage, $\%=\frac{\text { Number of damaged corms in } 15 \mathrm{~m} \text { test run }}{\text { Total number of corms droppedin } 15 \mathrm{~m} \text { test run }} \times 100$

\section{Number of corms per meter length (NCPM)}

One meter long strip was selected randomly from the test run and the number of corms dropped within this was counted. The procedure was replicated three times to obtain the average number of corms per meter length (Yasir et al., 2012).

\section{Results and Discussion}

\section{Mean spacing}

The observed corm spacing was measured during the test for all the three nominal spacings at four levels of forward speeds. The result (Table 1) showed that the observed spacing was quite close to the desired nominal spacing of the corms. The ratio of mean to nominal spacing was found to increase with the increase in level of forward speed. The 
value of the same was also found to decrease with increase in nominal spacing. This is may be due to improper functioning of metering device at higher levels of forward speeds. At higher levels of forward speeds the time available for cell fill could be less as compared to time available at lower level of forward speeds resulting into missing. On an average the value of ratio of mean to nominal spacing was found close to one at forward speeds of $1.5,2.0$ and $2.5 \mathrm{~km} / \mathrm{h}$ which indicated that the observed corm spacing was very close to the desired nominal spacing. The results of standard deviation and coefficient of variation did not show any trend with the change in forward speed and nominal spacing.

\section{Miss Index (MISS)}

The values of MISS for all the three levels of nominal spacings and four levels of forward speed were determined which indicated no missing of the corms at forward speed of 1.5 $\mathrm{km} / \mathrm{h}$ for all the three levels of nominal spacings. The miss index was observed to range between zero and $4.24 \%$ at forward speed of 2.0 and $3.0 \mathrm{~km} / \mathrm{h}$ for nominal spacing of 25 and $15 \mathrm{~cm}$ respectively. This indicated that the miss index increased with increase in forward speed and decreased with increase in nominal spacing. This may be due to higher speed operation of metering mechanism at resulting into lesser time availability for picking up of corm from the hopper. The same reason could be for higher missing at lower value of nominal spacing. The data was analyzed and the same was found statistically significant at $1 \%$ level of significance for various levels of forward speed and nominal spacings (Table 3 ).

\section{Multiple Index (MULTI)}

The mean values of MULTI for all the levels of nominal spacings and forward speeds were found zero (Table 2). This indicates that metering device did not drop the corms at spacing less than 0.5 times the nominal spacing.

\section{Quality Feed Index (QFI)}

The mean values of QFI were determined for all three nominal spacings and four levels of forward speed (Table 2). The result indicated higher quality feed index at forward speed of $1.5 \mathrm{~km} / \mathrm{h}$ for all the three nominal spacings. The acceptable limit of QFI has been suggested $\geq 90 \%$ (Kachman and Smith, 1995) for laboratory condition. The QFI values obtained during the experiment were found higher than the suggested values for all the levels of forward speed and nominal spacing. It was also observed that QFI was higher for lower level of forward speed and higher level of nominal spacing.

The reason for this may be due to lower MISS values and no MULTI resulted in higher percent of QFI. Similar results were observed by Singh and Gautam (2015) for Gladiolus corms in field condition. Forward speed and nominal spacing was found have significant effect on QFI at $p<0.01$ and $p<0.05$ respectively (Table 3 )

\section{Coefficient of Uniformity (CU)}

The coefficient of uniformity shows the evenness of corms delivered by metering device. The maximum and minimum values of CU were observed as 97.68 and $87.7 \%$ at forward speed of 1.5 and $2.0 \mathrm{~km} / \mathrm{h}$ for the nominal spacing of 25 and $15 \mathrm{~cm}$ respectively (Table 2). The results indicated that $\mathrm{CU}$ increased with increase in nominal spacing and decreased with increase in forward speed. The reason for this may be due to the fact that the cups of metering device got sufficient time for self-filling of corms at lower level of forward speed and for wider nominal spacing resulting in higher percent of $\mathrm{CU}$. The 
statistical analysis indicated significant effect coefficient of uniformity at $1 \%$ level of of speed of operation and nominal spacing on significance (Table 3).

Table.1 Observed mean spacing of corms during test in soil bin

\begin{tabular}{|c|c|c|c|c|c|}
\hline $\begin{array}{l}\text { Nominal } \\
\text { spacing, } \\
\text { cm }\end{array}$ & $\begin{array}{c}\text { Forward } \\
\text { speed, } \\
\text { km/h }\end{array}$ & $\begin{array}{c}\text { Mean } \\
\text { spacing, } \\
\text { cm }\end{array}$ & $\begin{array}{c}\text { Ratio of } \\
\text { mean/nominal } \\
\text { spacing }\end{array}$ & $\mathrm{SD}, \mathrm{cm}$ & CV \% \\
\hline \multirow[t]{4}{*}{$15 \mathrm{~cm}$} & 1.50 & 15.30 & 1.02 & 0.26 & 1.7 \\
\hline & 2.00 & 15.60 & 1.04 & 0.62 & 4.00 \\
\hline & 2.50 & 16.10 & 1.07 & 0.96 & 5.96 \\
\hline & 3.00 & 16.60 & 1.11 & 1.15 & 6.92 \\
\hline \multicolumn{2}{|r|}{ Mean } & 16.15 & 1.07 & 0.74 & 4.64 \\
\hline \multirow[t]{4}{*}{$20 \mathrm{~cm}$} & 1.50 & 20.20 & 1.01 & 0.85 & 4.13 \\
\hline & 2.00 & 20.50 & 1.03 & 1.42 & 6.92 \\
\hline & 2.50 & 21.10 & 1.06 & 1.3 & 6.16 \\
\hline & 3.00 & 21.50 & 1.08 & 1.49 & 6.95 \\
\hline \multicolumn{2}{|r|}{ Mean } & 20.95 & 1.05 & 1.26 & 6.04 \\
\hline \multirow[t]{4}{*}{$25 \mathrm{~cm}$} & 1.50 & 25.27 & 1.01 & 1.11 & 4.38 \\
\hline & 2.00 & 25.80 & 1.03 & 2.00 & 7.74 \\
\hline & 2.50 & 25.85 & 1.03 & 1.05 & 4.23 \\
\hline & 3.00 & 26.39 & 1.06 & 0.96 & 3.79 \\
\hline \multicolumn{2}{|r|}{ Mean } & 25.32 & 1.01 & 1.28 & 5.03 \\
\hline
\end{tabular}

Table.2 Results of Performance indices

\begin{tabular}{|c|c|c|c|c|c|c|c|}
\hline \multirow{2}{*}{$\begin{array}{l}\text { Nominal } \\
\text { spacing, } \\
\text { cm }\end{array}$} & \multirow{2}{*}{$\begin{array}{c}\text { Forward } \\
\text { speed, } \\
\text { km/h }\end{array}$} & \multicolumn{6}{|c|}{ Performance parameters } \\
\hline & & $\underset{\%}{\text { MISS, }}$ & $\underset{\%}{\text { MULTI, }}$ & $\begin{array}{c}\text { QFI, } \\
\%\end{array}$ & $\begin{array}{c}\mathrm{CU}, \\
\%\end{array}$ & $\begin{array}{c}\text { PREC, } \\
\%\end{array}$ & $\begin{array}{c}\text { CP3, } \\
\%\end{array}$ \\
\hline \multirow[t]{4}{*}{15} & 1.5 & 0.00 & 0.00 & 100.00 & 93.20 & 5.10 & 81.89 \\
\hline & 2.0 & 1.96 & 0.00 & 98.04 & 90.10 & 6.10 & 76.66 \\
\hline & 2.5 & 3.57 & 0.00 & 96.43 & 88.10 & 7.12 & 73.14 \\
\hline & 3.0 & 4.24 & 0.00 & 95.76 & 87.70 & 8.10 & 65.87 \\
\hline \multicolumn{2}{|r|}{ Mean } & 2.44 & 0.00 & 97.56 & 89.78 & 6.61 & 74.39 \\
\hline \multirow[t]{4}{*}{20} & 1.5 & 0.00 & 0.00 & 100.00 & 96.54 & 4.60 & 79.38 \\
\hline & 2.0 & 0.35 & 0.00 & 99.65 & 94.60 & 5.80 & 75.90 \\
\hline & 2.5 & 2.20 & 0.00 & 97.80 & 92.12 & 7.50 & 70.13 \\
\hline & 3.0 & 4.10 & 0.00 & 95.90 & 90.12 & 7.50 & 64.00 \\
\hline \multicolumn{2}{|r|}{ Mean } & 1.66 & 0.00 & 98.34 & 93.35 & 6.35 & 72.35 \\
\hline \multirow[t]{5}{*}{25} & 1.5 & 0.00 & 0.00 & 100.00 & 97.68 & 5.60 & 79.09 \\
\hline & 2.0 & 0.00 & 0.00 & 100.00 & 96.54 & 5.50 & 74.33 \\
\hline & 2.5 & 2.20 & 0.00 & 97.80 & 95.32 & 7.10 & 68.23 \\
\hline & 3.0 & 3.20 & 0.00 & 96.80 & 91.23 & 7.90 & 63.68 \\
\hline & Mean & 1.35 & 0.00 & 98.65 & 95.19 & 6.53 & 71.33 \\
\hline
\end{tabular}


Table.3 Statistical analysis of results (p-values)

\begin{tabular}{|c|c|c|c|c|c|}
\hline & MISS & QFI & $\mathbf{C U}$ & PREC & CP3 \\
\hline Forward Speed (S) & $0.0001^{* * *}$ & $0.0001^{* *}$ & $0.0001^{* *}$ & $0.0001^{* *}$ & $0.0001^{*}$ \\
\hline Nominal Spacing (W) & $0.0001^{* *}$ & $0.02^{*}$ & $0.0001^{* *}$ & $0.714^{\mathrm{NS}}$ & $0.0001^{*}$ \\
\hline Interaction (SxW) & $0.0039^{* *}$ & $0.4854^{\mathrm{NS}}$ & $0.361^{\mathrm{NS}}$ & $0.656^{\mathrm{NS}}$ & $0.486^{\mathrm{Ne}}$ \\
\hline
\end{tabular}

Fig.1 Schematic diagram of cup-chain type metering mechanism

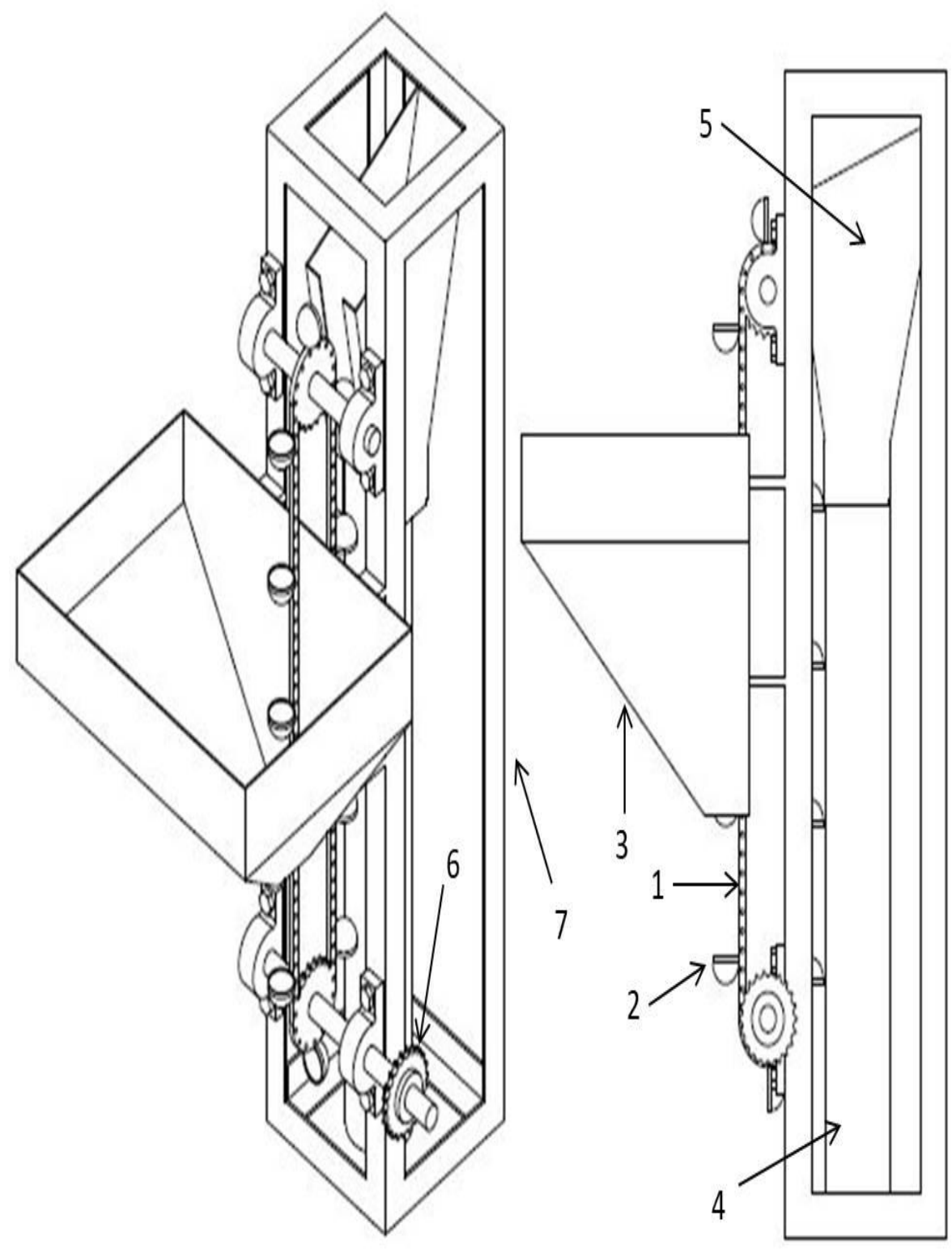

1. Cups

2. Chain

3. Hopper

4. Delivery Pipe

5. Funnel shape delivery chute

6. Sprocket

7. Frame 
Fig.2 Evaluation of metering device in soil bin

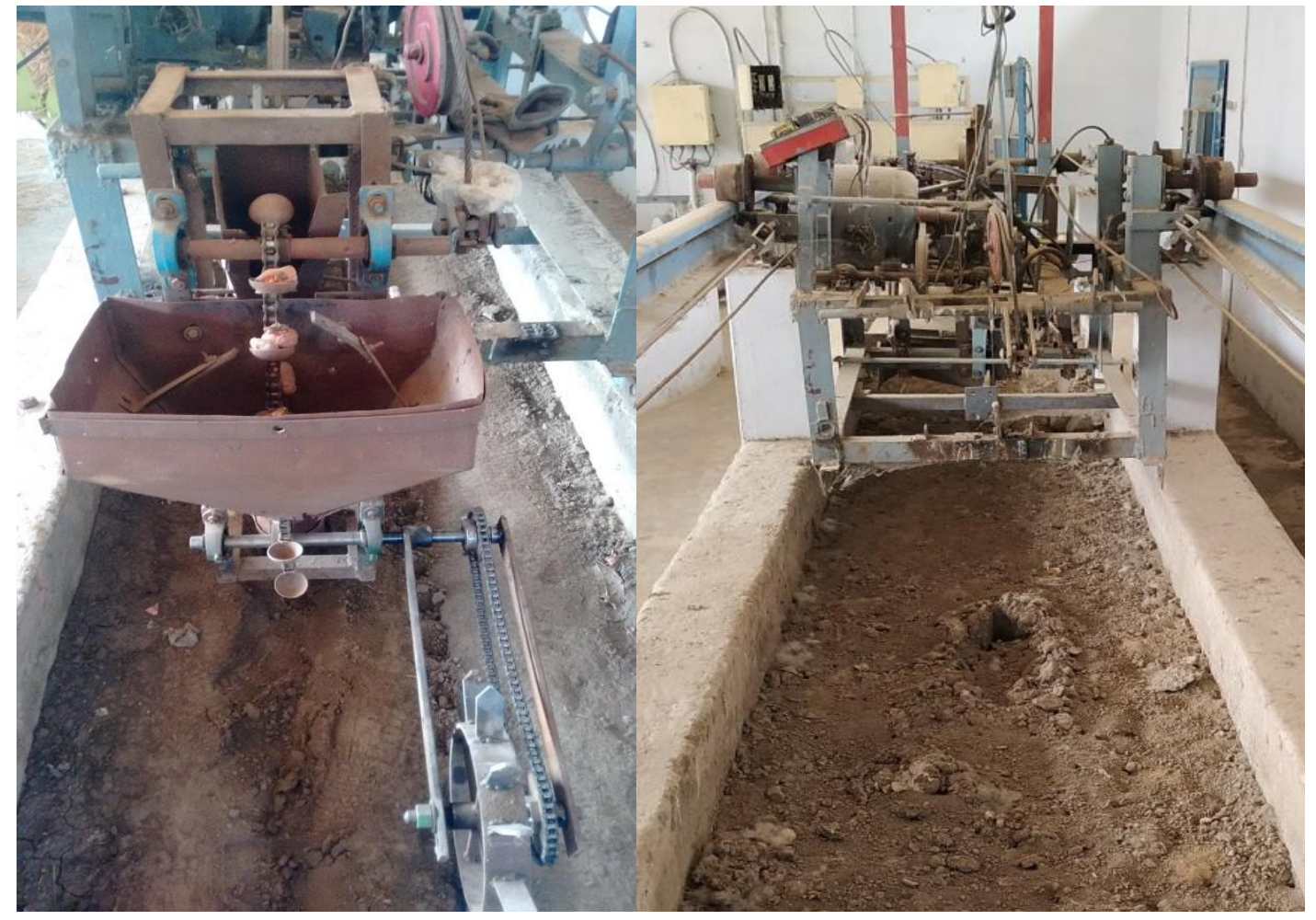

Fig.3 Relationship between visible corm damage and forward speed

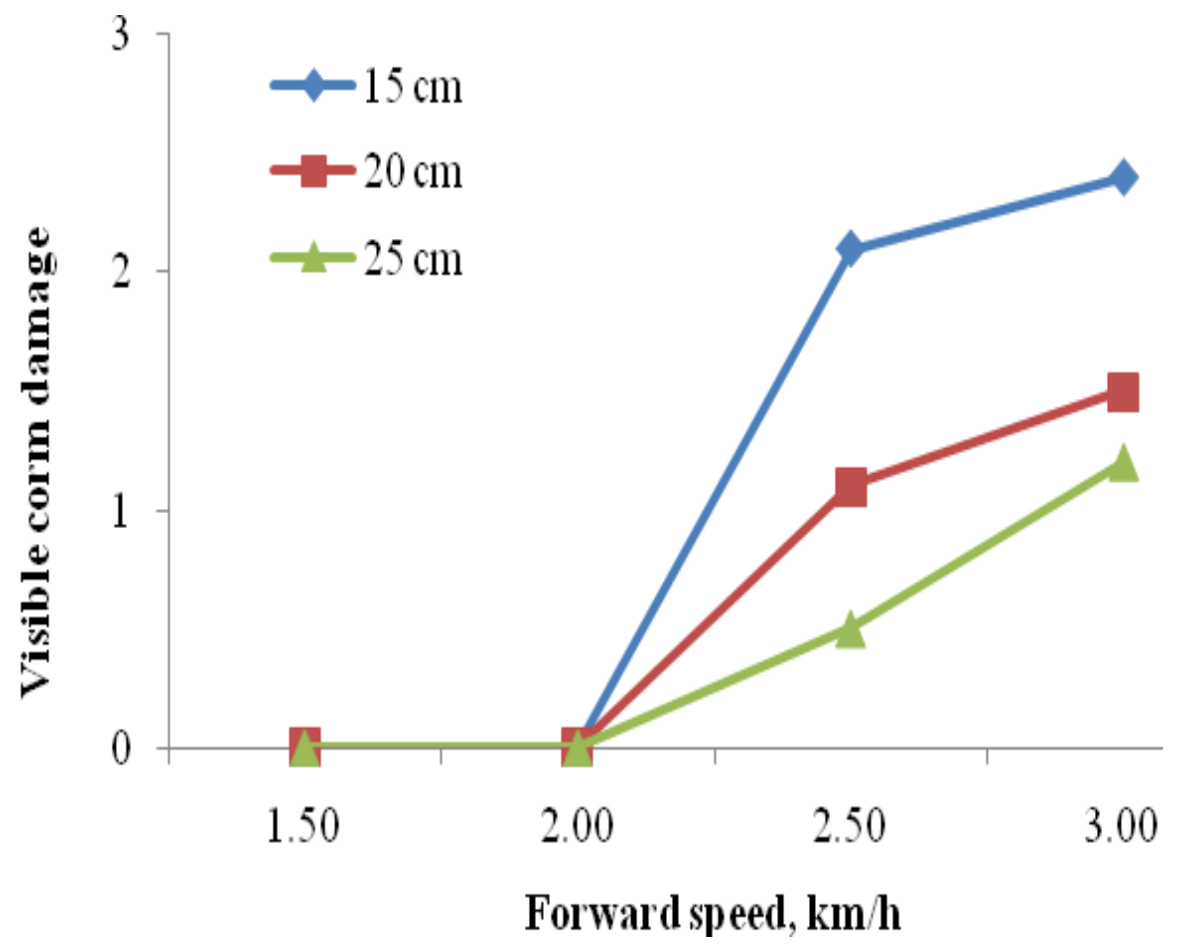


Fig.4 Number of corms per meter length

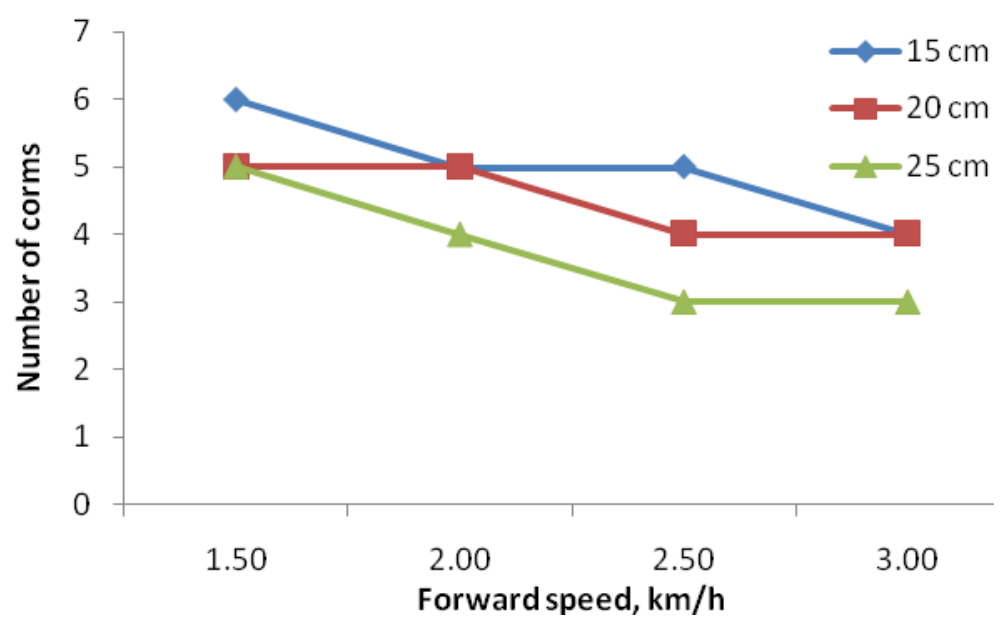

\section{Precision (PREC)}

The mean value of PREC was observed to range between 4.6 to 8.1 percent (Table 2). The minimum value of PREC was observed at lower level of forward speed for all the three nominal spacings whereas it was found maximum at higher level of forward speeds. This may be due to fact that the standard deviation of observed spacing found high at higher levels of forward speed resulting higher precision. The precision value of less than $10 \%$ is desirable for laboratory condition for better performance of precision planter as suggested by Kachman and Smith (1995). The result obtained indicated PREC value less than $10 \%$ for all the levels of forward speed and nominal spacing. Statistical analysis shows that forward speed highly affects the precision at $1 \%$ level of significance whereas the nominal spacing and interaction of these two parameters didnot show any effect on precision (Table 3 ).

\section{Coefficient of Precision (CP3)}

The CP3 value is related with the percentage of corms dropped by metering device within $\pm 1.5 \mathrm{~cm}$ of nominal spacing. The maximum and minimum values of $\mathrm{CP} 3$ were observed as
81.89 and $63.68 \%$ at forward speed of 1.5 and $3.0 \mathrm{~km} / \mathrm{h}$ for nominal spacing of 15 and $25 \mathrm{~cm}$ respectively (Table 2). The result indicated higher value of CP3 for $15 \mathrm{~cm}$ of nominal spacing at forward speed of $1.5 \mathrm{~km} / \mathrm{h}$ whereas it was observed minimum at higher forward speed of $3.0 \mathrm{~km} / \mathrm{h}$ and wider nominal spacing $(25 \mathrm{~cm})$.Higher $\mathrm{CP} 3$ values are desirable for better performance of metering device as suggested by Panning et al., 2000. The results indicted better performance of metering device at $1.5 \mathrm{~km} / \mathrm{h}$ forward speed for $15 \mathrm{~cm}$ nominal spacing. Results of statistical analysis showed that CP3values varied significantly at $1 \%$ level of significance for all the levels of forward speed and nominal spacing. However, the interaction terms were not found significant (Table 3).

\section{Visible corm damage}

Visible corm damage was observed during the experiment for all the three required nominal spacings at forward speed of 1.5, 2.0, 2.5 and $3.0 \mathrm{~km} / \mathrm{h}$ and is depicted in Fig. 2 which indicated no corm damage at forward speed of 1.5 and $2.0 \mathrm{~km} / \mathrm{h}$ for all the three nominal spacings. The maximum damage of corms $(2.4 \%)$ was observed at higher forward speed $(3.0 \mathrm{~km} / \mathrm{h})$ and lower level of nominal spacing 
$(15 \mathrm{~cm})$. The reason for this may be due to the stucking of corms occasionally between chain and collecting hopper. However, the visible corm damage was found within the acceptable limits of $\leq 0.5 \%$ (IS9856).

\section{Number of corms per meter}

Fig. 3 indicated the relationship between number of corms per meter length observed at various forward speeds and nominal spacings. The desired number of corms per meter length for 15,20 and $25 \mathrm{~cm}$ nominal spacing was determined 6,5 and 4 respectively. The required number of corms was observed at lower speeds of 1.5 and $2.0 \mathrm{~km} / \mathrm{h}$ for all three nominal spacings. However, it was observed less with increase in speed of operation beyond $2.5 \mathrm{~km} / \mathrm{h}$ which is due to higher values of MISS. It can be seen from the results that the performance of metering device found better at forward speeds of 1.5 and $2.0 \mathrm{~km} / \mathrm{h}$.

Based on the results of experiment, it could be concluded that the developed cup-chain type metering device should be operated at forward speed between 1.5 to $2.0 \mathrm{~km} / \mathrm{h}$ for its satisfactory performance. At the mentioned speed QFI was observed $100 \%$ with no corm damage for all the three nominal spacings.

\section{References}

Anonymous, 2016-17. National Horticulture Board. Ministry of Agriculture and Farmers welfare, Govt. of India

Bracy, R. P. and Parish, R. L. 1999.Seeding uniformity of precision seeders.
Horticulture. Techno. 8(2): 182-185.

Brinkmann, W., Flake, E. and Gehlen, A. 1980. Test: Einzelkornsaegeraete fur Zuckerruben, Die Landtechnishe Zeitschrift, Heft 3/80: 1-8.

IS 9856:1999 Indian Standard Test code for Potato Planter.

Jinqing, L., Ying, Y., Zihui, L., Qinqin, S., Jicheng, L. and Zhongyuan L. 2016. Design and experiment of an air suction potato seed metering device. Int. J. Agric. \& Biol. Eng. 9(5):33-42.

Kachman, S. D. and Smith, J. A. 1995. Alternative measures of accuracy in plant spacing for planters using single seed metering. Transactions of ASAE. 38:379387.

Kadvekar, S. (2018) Comparative performance of seed metering mechanisms for finger millet and barnyard millet. Thesis, M.Tech, GBPUA\&T, Pantnagar, Uttarakhand, India.

Panning, J. W., Kocher, M. F., Smith, J. A. and Kachman, S. D. 2000. Laboratory and field testing of seed spacing uniformity for sugarbeet planters. Applied Eng. In Agric. 16(1):7-13.

Rad, M., 2006. Design and development of a tworaw saffron bulb planter. AMA, 37(2):48.

Singh, P. and Singh, T. P. 2017. Performance evaluation of cell in belt type metering device for planting of gladiolus corms.Int. J. of Agric. Eng. 10(1):159-167.

Yasir, S. H., Liao, Q., Yu, J. and He, D. 2012. Design and test of a pneumatic precision metering device for wheat.Agric. Eng. Int. CIGR J. 14(1):16-25.

Yazgi, A. and Degirmencioglu, A., 2014. Measurement of seed spacing uniformity performance of a precision metering unit as function of the number of holes on vacuum plate. Measurement, 56: 128-135.

\section{How to cite this article:}

Ananda Kumar T. M. and Singh T. P. 2019. Development and Performance Evaluation of CupChain type Metering Mechanism for Gladiolus corms in the Soil Bin. Int.J.Curr.Microbiol.App.Sci. 8(08): 2813-2822. doi: https://doi.org/10.20546/ijcmas.2019.808.324 